\title{
Mammalian Expression System and Improvisation for High Production
}

\author{
Bindu Kodati ${ }^{1}$, Sailaja Darbha ${ }^{2}$ \\ ${ }^{1}$ Usha Biotech, 62/A, 1st Floor, Sundari Reddy Bhavan, Besides Heritage Fresh, Vengalrao Nagar, Hyderabad- 500038, India \\ ${ }^{2}$ Department of Biotechnology, GRIET, Bachupally, Hyderabad- 500090
}

\begin{abstract}
Recombinant proteins are of immense value both for research as well as for therapeutic use. Ever since insulin was introduced for therapeutic use there is lot of interest in the development of recombinant proteins as therapies. Recombinant proteins are often produced in heterologous host such as Bacteria, Yeast, Mammalian Cells, Transgenic Plants and Animals. Each one of these host cell lines have their own advantages and disadvantages. With the increase in the number of monoclonal antibody (mAb) based therapeutics at different stages of clinical trials is demanding for an efficient mammalian expression system. Mammalian expression system is often known to produce proteins with proper post-translational modification that were equivalent to that of humans. This review article is focused on strategies for increasing proteins production, host cell lines and the applications and products that were produced so far using mammalian expression systems. The purpose of writing this article is to summarise the advances in mammalian expression systems and their use.
\end{abstract}

Keywords: Mammalian Expression system, Host cell line, Applications, Recombinant proteins and Biopharmaceuticals

\section{Introduction}

The major part of biopharmaceuticals is protein based and extracted in recombinant hosts. For extracting some biopharmaceutical proteins, bacteriological systems are useful because they are cheap with higher output, and fast execution. In 1980 the industry has shifted towards the utilization of mammalian cells for the correctly folded protein production with suitable glycosylated patterns. Mammalian cells are favoured hosts for manufacturing of complex protein therapeutics, as the post translational modifications are functionally and pharmacokinetically compatible with humans. Stable cell lines which are an important requirement for production of biopharmaceutical proteins are developed by transfecting host cells with the suitable vector system with the gene of interest .The normal productivity scale achieved by using mammalian cells is 1 to $2 \mathrm{~g} / \mathrm{L}$ and recently it has been claimed to $10 \mathrm{~g} / \mathrm{L}$ in the production scale. Thus, during the last two centuries, cultured mammalian cells have became the platform for the production of recombinant proteins or therapeutics in spite of low productivity, high production cost, and other difficulties when compared with bacteriological systems. With the huge demand for production of monoclonal antibodies the capacity of cell culture volume has been increased from < 300,000 litres to approximately 3 million litres [1].

In case of mammalian and animal cell lines, most of the proteins are secreted with subsequent refolding rather than demanding cell lysis to extract as in case with prokaryotic system. The common nonhuman mammalian cell lines used for manufacturing of therapeutic proteins are Chinese hamster ovary $(\mathrm{CHO})$ cells, mouse myeloma cells (NSO and Sp2/0) and baby hamster kidney (BHK21) cells . The post translation modifications like galactose-a1, 3-galactose(agal) and N-glycolylneuraminic acid (NGNA) which are not expressed in human are also been produced by these nonhuman mammalian cell lines. As humans have circulating antibodies against to these $\mathrm{N}$-glycans, the clones with suitable glycan profiles are screened with utmost care when non-human mammalian cell lines are used for production of recombinant proteins [2].

\section{Improvements in Mammalian Expression System}

Mammalian expression improvements are accomplished by suitable vector design. Vectors possessing strong promoter for example cytomegalovirus (CMV) promoter to obtain higher level transcription of messenger RNA, correct signal peptide, specific introns and optimization of product gene codon for target cell type, balance of GC/AT ratio have shown to achieve the high level of gene expression by improving the secretion process and processing of mRNA. Utilization of transcription control units are also essential . Gene amplification system is the most reliable method brought about by selective marker utilization for example DHFR or glutamine synthetase (GS) for the generation of cell lines. There are around 200 recombinant biopharmaceutical products available in the market and many more are under clinical improvement. Most of the proteins products are glycosylated. An expression system permitting effective production of quality glycoprotein is very important. For the maintenance of long time residence in circulation the sialylation of glycoproteins is very essential. The degree of sialylation varies depending on the type of product, the hose cell line used and the culture conditions maintained for the growth. The biosynthesis of sialic acid, obtainability of nucleotide-sugars, and CMP sialic acid transporter and the sialyl-transferase are the limiting steps for sialylation [3].

\subsection{Gene Integration}

The positional integration of recombinant gene affects the rate of transcription. The negative effect of random integrations like exogenous gene silencing has been overcome by uses the different strategies. A cis-regulated 


\section{International Journal of Science and Research (IJSR) \\ ISSN (Online): 2319-7064 \\ Index Copernicus Value (2013): 6.14 | Impact Factor (2015): 6.391}

positive insulator element, Ubiquitous chromatin opening elements (UCOE) is used to increase transgene expression stability. UCOE is an un-methylated $\mathrm{CpG}$ island fragments which contains the chromatin in an open, non tissue specific manner that allows the gene integration in an independent manner for rapid expression in a vector. There is a significant increase in production even with the single copy integrations when vectors with UCOE are used for e.g. mAb production by six fold increase in $\mathrm{CHO}$ cells. In less than one month from transfection, rapid Production of 300mg has been reported when UCOE are used in combination with serum free media and suspension cell lines [3],[4].

Matrix attachment regions (MARs) are the attachment points of DNA which promotes the gene expression. The chromatin structure is maintained trancriptionally active by the MARS with the creation of chromatin loops. The demethylation of DNA may occur indirectly with increase in histone hyperacetylation by which it will be easily accessible for the transcription machinery by flanking the transgene [4]. The site specific homologous recombination can be achieved by the use of particular recombinases which catalyzes the integration of gene of interest into the hot spot of host cell line. The specific attachment regions are crucial for this type of recombination. The specific enzymes like P1 Cre recombinase from bacteriophage, integrase from lambda phage and FLP from yeast are mostly used to enhance the integration of target genes [4],[5].

\subsection{Gene targeting}

The engineered chromosomes have to be considered for the improvisation of transfection process. For the targeted cell transfection, a mammalian-based artificial chromosome expression (ACE) System with an ACE targeting vector (ATV) and ACE $\lambda$ integrase (attP attachment site) for recombination acceptor sites are used. This type of recombinant gene targeting without the use of gene amplification system helps to achieve high copy number producers under selection pressure by promoterless marker gene activation. More than $500 \mathrm{mg} / \mathrm{L}$ in batch terminal shake flask was produced by using ACE platform cell line for monoclonal antibodies [4],[6].The cultivated mammalian cells can be integrated with the gene of interest by using the transposable elements like PiggyBac (PB) and sleeping beauty [7],[8]. In absence of selection pressure, the $\mathrm{CHO}$ cells transfected by PiggyBac showed stability for 3 month and an increase in the expression of fusion protein of tumor necrosis factor -Fc [9].

\subsection{Cell Line Engineering}

The time integral of viable cell density (IVCD) and the productivity of specific protein(q) are the important factors which influence the quantity of the recombinant protein expression. The strategies for improvement of high production by cell line engineering include extension of cell culture longitivity, specific growth acceleration and modification of cellular functions [4]. cell lines has been engineered by inserting the Proto-Oncogenes, apoptosis inhibitor genes, cell cycle controlling genes (cyclins) and various growth factor genes [10]. The specific production and secretions has been enhanced by the expression of X-box binding protein 1 (XBP-1) in $\mathrm{CHO}$ cells by the utilization of combined technology of the anti apoptosis and secretion engineering. Introduction of X-linked inhibitor of apoptosis (XIAP) by transfecting the cell line to reduce the programmed cell death has increased the titers to $60 \%$ [4].

The latest technologies with the help of protein domains like zinc finger proteins and the transcription activator like effectors (TALEs) are designed for the specific DNA sequence recognition. By fusing these protein domains with the specific endonucleases domains the target sites are created and can cut at particular DNA sequences. Fok $\mathrm{I}$ is the mostly used endonuclease domain for this purpose as it doesn't possess any specific site for cleavage and dimerization of DNA is required for cleavage [4],[11].Triple knockout genes were developed in $\mathrm{CHO}$ cells using the Zinc Finger nucleases which includes the knockout of dihydrofolate reductase (DHFR) and glutamine synthase (GS) genes for the selection of high gene copy clones and $\alpha 1,6$-fucosyltransferase8 (FUT8) [12] for the production of non-fucosylated $\operatorname{IgG1}$ with strong therapeutic potential increased antibody dependent cell mediated cytotoxicity (ADCC) in humans in vivo at very low dosages [13],[14]. Development of Faster cells lines were generated and launched by Lonza using knockout of GS gene in CHO cell lines by the ZFN technology [15]. Use of Meganucleases and in silico modeling coupled with OMICS tools are the latest tools used in the cell line development for the enhanced stability and high expression of the recombinant proteins. [16],[17]. The latest technology with small interfering RNA is used to change the gene regulations in cells and the in silencing of genes for multiple targets for the better production in CHO cell lines [18]

\subsection{Process development}

The important factors like optimization of medium and the feeding strategies have been employed to increase production rate [5],[19]. By using the high end $\mathrm{pH}$ controlled feeding strategy for the lactate effect, the $\mathrm{mAb}$ and other recombinant protein production titers has been doubled in almost all $\mathrm{CHO}$ cell lines from bench to large scale production [20].The fed batch process with the highly defined chemical media reportedly increased the production rate from $44 \mathrm{p} / \mathrm{c} / \mathrm{d}$ to $54 \mathrm{p} / \mathrm{c} / \mathrm{d}$ using plant hydrolysate and the maximum titer of $10-13 \mathrm{~g} / \mathrm{L}$ of $\mathrm{mAb}$ and $\mathrm{Fc}$-fusion protein [19]. Raman spectroscopy is used to analyze and maintain the consistency of the media components for large scale production [21]. Cryobag banking procedure was generated to shorten the time period from seed development to inoculums for production [22].

The injuries by sparging and the agitation in stirred tank bioreactors for mammalian cells has been greatly reduced with the use of Pluronic F-68 ( a synthetic nonionic surfactant) [23],[24].Improved yield by $30-40 \%$ of $\mathrm{mAb}$ production was achieved by the use of $0.25 \mathrm{mM}$ iron and $05 \mathrm{mM}$ sodium citrate [25]. The aggregation effect during the recombinant protein production has been reduced by lowering the $\mathrm{pH}$ and maintaining the osmolarity by adding the sodium chloride in the culture medium [26]. The chromatographic techniques like size exclusion, hydrophobic interaction and dextran-grafted agarose based ion exchange 


\section{International Journal of Science and Research (IJSR) \\ ISSN (Online): 2319-7064 \\ Index Copernicus Value (2013): 6.14 | Impact Factor (2015): 6.391}

resin are gaining interest in downstream process for aggregate removal and bioseparation [3].

\section{Host Cell Lines}

The choice of host cell line and the appropriate vectors are very important, as they show significant impact on gene expression levels. Some host cell lines which are used in biopharmaceutical protein production are as follows:

\subsection{Chinese Hamster Ovary cells}

$\mathrm{CHO}$ are the hugely popular mammalian cell model used in biology, medical and pharmaceutical research which are commercially used for the manufacture of therapeutic recombinant proteins. $\mathrm{CHO}$ cell were derived from the ovary cells of partially inbred, female adult Chinese hamster. Post-translational modifications in these cells are proven to closely mimic that of human cells [4],[27],[28]. The main advantages of $\mathrm{CHO}$ cell lines which made them as suitable as a host cell are: (a) Extremely high productivity levels can be reached in CHO cells ( approx 4-5 $\mathrm{gL}^{-1}$ ) [29] (b) safe production system is provided by $\mathrm{CHO}$ cell line which pose low risk from infectious or virus-like particles (c) $\mathrm{CHO}$ cells have been characterized extensively and are easy to manipulate genetically (d) Using serum-free media good proliferation of $\mathrm{CHO}$ cells can be achieved in suspension cultures to a maximum viable cell density of $\geq 1 \times 10^{7}$ cells/mL [29] (f)The two common CHO derivatives are $\mathrm{CHO}-\mathrm{K} 1$ and $\mathrm{CHO}$ pro-3. The mutation of these derivatives gave rise to the CHO-DXB11 (CHO-DUKX) and CHODG44 which are mostly used cell lines in bioprocessing today as these are deficient in dihydrofolate reductase (DHFR) activity, which makes it useful for easy selection.

\subsection{Mouse myeloma cell line (NS0)}

NS0 cells were derived from the plasmacytoma cell line which was originated from BALB/c mouse. Though the origin is from the differentiated B cell, NSO lack the immunoglobulin synthesis and secretion due to evolution and is the non light chain synthesizing derivative of subclone NS1[30],[31]. This main feature of NS0 (Non Secreting Null) made it a powerful cell line for the production of high yields of immunotherapeutics. NSO cells are auxotroph of glutamine and cholesterol. The deficiency of glutamine synthetase (GS) system made them useful as recombinant expression systems by utilizing GS as a selectable marker [32]. The key advantages of NS0 are (a) they can be grown in protein-free chemically defined medium [33], (b) The history of NS0 is well known and are well characterised [31], (c) less regulatory constraints as some NS0 expressed products [Zenapax (dacliximab) and Synagis (palivizumab)] have been commercialized [31].

\subsection{PER.C6}

PER.C6 (WO. 97/00326) is a novel human immortalized cell line specifically designed for biopharmaceutical production. It was derived from single healthy human embryonic retinal cells by transfecting with a plasmid that has the E1A and E1B coding sequences of adenovirus serotype 5 (Ad5 nucleotide 459-3510) which is under the control of the human PGK (phosphoglycerate kinase) promoter [34]. The specific features of PER.C6 which made if particularly useful as a host ; (a) it is originated from human lineage and has fully characterized history, (b) it was developed in high compliance with good laboratory practice, (c) with a doubling time of $35 \mathrm{~h}$, its growth is compatible with shaker and spinner flasks, roller bottles, bioreactors, (d) the presence of E1A enhances the transcription of genes which are under the control of the enhancer or promoter of CMV immediate early genes [35],[36] (e) the presence of E1B prevents p53- dependent apoptosis by binding with Bax and Bak proteins possibly enhanced through recombinant transgene over-expression [37] (f) expression platform does not require amplification of the incorporated gene or selection agent [30],[38].

\section{Applications and Products from Mammalian Host Lines}

The first recombinant protein, human insulin was licensed for use by US FDA in 1982 (Genentech). Following this approval, in 1987 human tissue plasminogen activator (tPA Activase; Genentech, S. San Francisco, CA, USA) became the first therapeutic complex glycosylated protein from recombinant mammalian cells to get market approval. Since then biologics production in mammalian cells dominates with about $60-70 \%$.In addition hundreds of products are in pipeline as clinical candidate proteins [5]. Between 20062011, FDA has approved as average of fifteen new biologicals every year[4]. For the treatment of various illnesses more than 165 biotherapeutic agents are licensed and reached global sales of over $\$ 99$ billion[39],[ 40].

Over past 25 years though many systems have generated the biologics, for the manufacture of complex glycoproteins the predominant expression host cell lines are the immortalized Chinese hamster ovary (CHO) cells [41]. cell lines other than $\mathrm{CHO}$, such as NSO derived from mouse myeloma cells,PER.C6 derived from human retinal cells, BHK from the kidneys of 5 Syrian hamsters, HEK-293 from human embryonic kidney cells have gained regulatory approval for production of recombinant protein [5]. Few of the products produced by using mammalian expression systems are mentioned below.

\subsection{Vaccines}

Mammalian cell-based vaccine technology produced various viral vaccines efficiently. The commercialized Hepatitis B Vaccine (GenHevacR) produced in the $\mathrm{CHO}$ cell lines contains all the three HBsAg forms that is the $\mathrm{S}$ protein, the pre S-I and pre S-2 antigen which confirms the immunogenicity of the vaccine, when compare with the yeast which produced only one form. [42,43]. Egg free method of Novel 2009 H1N1 influenza vaccine virus was developed by FluGen Inc., with its proprietary $\mathrm{CHO}$-cell-based production system (www.flugen.com.). Egg free method of seasonal influenza vaccine (Flucelvax) was developed by the Novartis by propagating the viruses in Madin Darby Canine Kidney (MDCK) cells and achieved the approval from FDA in 2012 for seasonal flu prevention in people over age 18 [44]. New 


\section{International Journal of Science and Research (IJSR) \\ ISSN (Online): 2319-7064 \\ Index Copernicus Value (2013): 6.14 | Impact Factor (2015): 6.391}

targets for the cell-based vaccines are human immunodeficiency virus (HIV) and herpes simplex virus.

\subsection{Hormones and Growth Factors}

The reproductive functions are directly or indirectly regulated by gonadotrophin hormones. The adverse effects can be treated by of recombinant hormone administration. $\mathrm{CHO}$ cells derived recombinant human choriogonadotrophin (rhuCG) is used in the treatment of ovalatory infertility [45]. CHO cell derived Recombinant follicles stimulating hormone ( $\mathrm{rFSH})$ for treatment of fertility disorder is safe and effective [46].

Recombinant human erythropoietin (rhuEPO), a Haemopoietic growth factors is most widely used in the treatment of anaemia. Epoetin alfa, beta and omega are the three varieties of rhuEPO available for clinical use [47- 50]. Epoetin alfa and beta are produced in CHO cells and epoetin omega is produced in BHK cells. Recently, Darbepoetin alfa, a novel erythropoiesis stimulating protein was developed recently for the treatment of anaemia [51]. HT-1080 human cell line produced the Epoetin delta (DYNEPO®) which was approved by EMA 2002 but later was voluntarily withdrawn by the manufacturer for the treatment of anemia secondary to chronic renal failure[52],[53].

\subsection{Blood coagulation factors}

The most bleeding disorders are caused by the deficiency of Human coagulation factors. Deficiency of human coagulation factors VIII and IX leads to haemophilia A and haemophilia B respectively [54],[55].CHO cell line derived recombinant human factor VIII containing 1438 amino acids provided a temporary replacement for people suffering with haemophilia A [55] and recombinant factor IX containing 415 amino acids controlled bleeding events in patients with haemophilia B [56]. A unique haemostatic agent derived from BHK cells, Recombinant factor VIIa containing 406 amino acids got approval for treating the patients who acquired antibodies to human factor VIII and IX and people with congenital bleeding abnormalities [57],[58].

The recombinant fusion proteins $\mathrm{rFVIIIFc}$ and $\mathrm{rFIXFc}$ ( Biogen, Cambridge, MA) from HEK293 cells got approval from the FDA in 2014 for the treatment of bleeding episodes in people suffering with hemophilia A and B [59]- [62]. For the management of hemophilia $\mathrm{A}$, an additional replacement product for factor VIII , Human-cl rhFVIII (NUWIQ; Octapharma, Lachen, Switzerland) was derived from the HEK293-F cell line which has got approval from EMA and submitted for FDA approval [63].

\subsection{Other Recombinant proteins}

Many other recombinant proteins are produced using the mammalian expression system. Mammalian host cell lines for therapeutic antibodies production includes Murine myeloma cell lines (NS0 and Sp2/0), PER.C6 ${ }^{\circledR}$ cells and Chinese hamster ovary $(\mathrm{CHO})$ cells. palivizumab and ofatumumab are the $\mathrm{mAb}$ produced from Murine myeloma cells [31],[64].The recombinant human interferon rhuIFN alpha-2b is used for the treatment of various diseases like hairy cell leukaemia, renal cell carcinoma, malignant melanoma ,hepatitis B and C [65],[66]. The enzyme prepared from CHO cells, dorsase alfa (rhudeoxyribonuclease 1) [ 67] is specifically used for cystic fibrosis to reduce mucous viscosity. HEK293-EBNA cells derived recombinant fusion protein, Glucagon-1-like peptide (GLP-1) Fc (dulaglutide) for the treatment of type 2 diabetes mellitus got the approval from the FDA[68],[69]. Many of the products from PER.C6 cell line are under phase 1 or 2 clinical trials [70], including MOR103 mAb for treatment of rheumatoid arthritis and multiple sclerosis [71] and CL184 for treatment against the rabies virus [72].

\section{Conclusion}

Mammalian expression system has increasingly gained interest from the last two decades and became the dominant biopharmaceutical production system for clinical applications. This is due the ability of mammalian expression system to produce the proteins in fully biological active form and often show less immunogenicity. Significant progress is made to simplify the cell line development process and increase productivity. With the existing expression systems and processes industry is now able to develop high producing clone in less than 3 months with a productivity of $10 \mathrm{~g} / \mathrm{L}$ [1]. This review has summarized the latest advances in the field of mammalian expression of recombinant proteins for biopharma development especially in areas such as expression vectors, host cell lines and proteins.

\section{References}

[1] Jinyou Zhang : Mammalian Cell Culture for Biopharmaceutical Production. In book: Manual of Industrial Microbiology and Biotechnology, Edition: 3rd ed., Chapter: 12, Publisher: ASM Press, Washington, DC., pp.157 - 178

[2] Darius Ghaderi, Rachel E. Taylor, Vered PadlerKaravani, Sandra Diaz, and Ajit Varki, "Implications of the presence of N-glycolylneuraminic Acid in Recombinant Therapeutic Glycoproteins," Nat Biotechnol, Aug; 28(8), pp 863-867, 2010.

[3] Jianwei Zhu, "Mammalian cell protein expression for biopharmaceutical production," Biotechnol Adv. (5):1158-70,2012.

[4] Tingfeng Lai, Yuansheng Yang and Say Kong Ng, "Advances in Mammalian Cell Line Development Technologies for Recombinant Protein Production," Pharmaceuticals, 6, 579-603, 2013.

[5] Florian M Wurm, "Production of recombinant protein therapeutics in cultivated mammalian cells," Nature Biotechnology ,22, 1393 - 1398 ,2004.

[6] Kennard ML, " Engineered mammalian chromosomes in cellular protein production: Future prospects," Methods Mol Biol,738:217-38, 2011.

[7] Ding S, Wu X, Li G, Han M, Zhang Y, Xu T, "Efficient transposition of the piggyback (PB) transposon in mammalian cells and mice," Cell, 122:473-83, 2005

\section{Volume 5 Issue 6, June 2016 www.ijsr.net}




\section{International Journal of Science and Research (IJSR) \\ ISSN (Online): 2319-7064}

Index Copernicus Value (2013): 6.14 | Impact Factor (2015): 6.391

[8] Wu SC, Meir YJ, Coates CJ, Handler AM, Pelczar P, Moisyadi S, et al,"PiggyBac is a flexible and highly active transposon as compared to sleeping beauty, Tol2, and Mos1 in mammalian cells," Proc Natl Aced Sci U S A ,103:15008-13, 2006.

[9] Matasci M, Baldi L, Hacker DL, Wurm FM, "The piggyBac tansposon enhances the frequency of $\mathrm{CHO}$ stable cell line generation and yields recombinant lines with superior productivity and stabilit,". Biotechnol Bioeng, 108:2141-50, 2011.

[10] Arden, N., Nivtchanyong, T. \& Betenbaugh, M.J, "Cell Engineering blocks stress and improves biotherapeutic production," Bioprocessing 3, 23-28, 2004.

[11] Miller, J.C., Holmes, M.C., Wang, J., Guschin, D.Y., Lee, Y.L., Rupniewski, I., Beausejour, C.M., Waite, A.J., Wang, N.S., Kim, K.A. et al, "An improved zincfinger nuclease architecture for highly specific genome editing," Nat. Biotechnol., 25, 778-785, 2007.

[12]Liu, P.Q., Chan, E.M., Cost, G.J., Zhang, L., Wang, J., Miller, J.C., Guschin, D.Y., Reik, A, Holmes, M.C., Mott, J.E., et al, " Generation of a triple-gene knockout mammalian cell line using engineered zinc-finger nucleases," Biotechnol. Bioeng., 106, 97-105, 2010.

[13] Lida S,Misaka H, InoueM, Shibata M, Nakano R, Yamane-Ohnuki N, et al, "Nonfucosylated therapeutic IgG1 antibody can evade the inhibitory effect of serum immunoglobulin $\mathrm{G}$ on antibody-dependent cellular cytotoxicity through its high binding to FcgammaRIIIa."Clin Cancer Res 12:2879-88, 2006.

[14] Wong AW, Baginski TK, Reilly DE, " Enhancement of DNA uptake in FUT8-deleted CHO cells for transient production of afucosylated antibodies," Biotechnol Bioeng ,106:751-63, 2010.

[15]Fan, L., Kadura, I., Krebs, L.E., Hatfield, C.C., Shaw, M.M., Frye, C.C," Improving the efficiency of $\mathrm{CHO}$ cell line generation using glutamine synthetase gene knockout cells," Biotechnol. Bioeng., 109, 10071015,2012 .

[16] Cabaniols, J.P., Ouvry, C., Lamamy, V., Fery, I., Craplet, M.L., Moulharat, N., Guenin, S.P., Bedut, S., Nosjean, O., Ferry, G., et al,"Meganuclease-driven targeted integration in CHO-K1 cells for the fast generation of HTS-compatible cell-based assays," J. Biomol. Screen., 15, 956-967,2010.

[17] Datta, P., Linhardt, R.J., Sharfstein, S.T," An 'omics approach towards $\mathrm{CHO}$ cell engineering," Biotechnol. Bioeng., 110, 1255-1271, 2013.

[18] Wu SC," RNA interference technology to improve recombinant protein production in Chinese hamster ovary cells," Biotechnol Adv, 27:417-22, 2009.

[19]Huang Y-M, Hu WW, Rustandi E, Chang K, YusufMakagiansar $\mathrm{H}$," Maximizing productivity of $\mathrm{CHO}$ cellbased fed-batch culture using chemically defined media conditions and typical manufacturing equipment," Biotechnol Prog, 26:1400-10, 2010.

[20] Gagnon M, Hiller G, Luan Y-T, Kittredge A, DeFelice J, Drapeau D," High-end pH-controlled delivery of glucose effectively suppresses lactate accumulation in CHO fed-batch cultures," Biotechnol Bioeng, 108:132837, 2011.

[21]Li B, Ryan PW, Ray BH, Leister KJ, Sirmuthu NM, Ryder AG,"Rapid characterization and quality control of complex cell culture media solutions using raman spectroscopy and chemometrics," Biotechnol Bioeng, 107:290-301, 2010.

[22] Heidemann R, Lunse S, Tran D, Zhang C, "Characterization of cell-banking parameters for the cryopreservation of mammalian cell lines in 100-mL cryobags," Biotechnol Prog, 26:1154-63, 2010.

[23] Clincke M-F, Guedon E, Yen FT, Ogier V, Roitel O, Goergen J-L," Effect of surfactant Pluronic F-68 on $\mathrm{CHO}$ cell growth, metabolism, production, and glycosylation of human recombinant IFN- $\gamma$ in mid operating conditions," Biotechnol Prog, 27:181-90, 2011.

[24] Murhammer DW, Goochee CF, "Structural features of nonionic polyglycol polymer molecules responsible for the protective effect in sparged animal cell bioreactor," Biotechnol Prog, 95:39-48, 1990.

[25] Bai Y, Wu C, Zhao J, Liu YH, Ding W, Ling WLW, "Role of iron and sodium citrate in animal protein-free $\mathrm{CHO}$ cell culture medium on cell growth and monoclonal antibody production," Biotechnol Prog, 27:209-19, 2011.

[26]Franco R, Daniela G, Fabrizio M, Ilaria G, Detlev H, "Influence of osmolarity and $\mathrm{pH}$ increase to achieve a reduction of monoclonal antibodies aggregates in a production process," Cytotechnology, 29:11-25, 1999.

[27] Olijve, W., de Boer, W., Mulders, J. W. and van Wezenbeek, P. M,"Molecular biology and biochemistry of human recombinant follicle stimulating hormone (Puregon), " Molecular Human Reproduction 2, 371382, 1996.

[28] Puck TT, C. S., Robinson A.," Genetics of somatic mammalian cells. III. Long-term cultivation of euploid cells from human and animal subjects," journal of experimental methods, 108, 945, 1958.

[29] Vernon, A," The GS Gene Expression System." pp. 1-3, Lonza Biologics Plc, 2004.

[30] Richard H. Baltz, Arnold L. Demain, Julian E. Davies, Manual of Industrial Microbiology and Biotechnology (book);American Society for Microbiology Press, 25Mar-2010

[31]Barnes LM, Bentley CM, Dickson AJ," Advances in animal cell recombinant protein production: GS-NS0 expression system," Cytotechnology. Feb;32(2), 109-23, 2000.

[32] Bebbington, C. R., Renner, G., Thomson, S., King, D., Abrams, D. and Yarranton, G. T.," High-level expression of a recombinant antibody from myeloma cells using a glutamine synthetase gene as an amplifiable selectable marker," Bio/Technology 10, 169175,1992 .

[33] Gorfien, S., Paul, B., Walowitz, J., Keem, R., Biddle, W. and Jayme, D.," Growth of NS0 cells in protein-free, chemically defined medium," Biotechnology Progress 16, 682-687, 2000.

[34] Havenga MJ, Holterman L, Melis I, et al., " Serum-free transient protein production system based on adenoviral vector and PER.C6 technology: high yield and preserved bioactivity," Biotechnol Bioeng, 100, 273-83, 2008.

[35] Olive DM, Al-Mulla W, Simsek M, Zarban S, al-Nakib W," The human cytomegalovirus immediate early enhancer-promoter is responsive to activation by the adenovirus-5 13S EIA gene," Arch Virol . 112, 67-80, 1990 .

\section{Volume 5 Issue 6, June 2016 www.ijsr.net}




\section{International Journal of Science and Research (IJSR) \\ ISSN (Online): 2319-7064}

Index Copernicus Value (2013): 6.14 | Impact Factor (2015): 6.391

[36] Gorman CM, Gies D, McCray G, Huang M, "The human cytomegalovirus major immediate early promoter can be trans- activated by adenovirus early proteins," Virology 171, 377- 385, 1989.

[37] Hateboer G, V. K., Schouten GJ, Uytdehaag AG, Bout A."Recombinant protein production in a human cell.," Crucell Holland B.V. (Leiden, NL) NL, 2005.

[38] Jones D, Kroos N, Anema R, et al.," High-level expression of recombinant $\mathrm{IgG}$ in the human cell line per.c6," Biotechnol Prog, 19,163-8, 2003.

[39] Strohl WR, Knight DM, "Discovery and development of biopharmaceuticals: current issues,"

Biotechnol. Dec;20(6):668-72, 2009.

[40] Walsh G.,"Biopharmaceutical benchmarks 2010," Nat Biotechnol. Sep;28(9):917-24, 2010.

[41] Jamie Freeman, "Heading for a CHO Revolution: The Need for Cell Line Engineering to Improve Manufacturing Cell Lines," BioProcess International, January 13, 2016.

[42] Roldao A, Mellado MC, Castilho LR, Carrondo MJ, Alves PM.,"Virus-like particles in vaccine development," Expert Rev Vaccines. Oct;9(10):1149-76, 2010.

[43]H. Qureshi ,T. Ahsan M. Memon ," Efficacy of CHO Cell derived Hepatitis B Vaccine in Children and Adults," Journal Of Pakistan Medical Association March, 2002 .

[44]Bsargent, "A First - Cell Culture Based Seasonal Influenza Vaccine Approved by the FDA" 2012 (http://cellculturedish.com/2012/12/a-first-cell-culturebased-seasonal-influenza-vaccine-approved-by-the$\mathrm{fda} /$ ).

[45]Lathi, R. B. and Milki, A. A., "Recombinant gonadotropin," Curr.Women's Health Rep., 1, 157-163, 2001.

[46] Hugues, J. N.,"Recombinant human follicle-stimulating hormone: A scientific step to clinical improvement," Reprod. Biomed. Online, 2, 54-64, 2001.

[47] Markham, A. and Bryson, H. M., "Epoetin alfa, a review of its pharmacodynamics and pharmacokinetic properties and therapeutic use in nonrenal application," Drugs, 49, 232-254, 1995.

[48] Dunn, C. J. and Markham, A.," Epoetin beta, a review of its pharmacological properties and clinical use in the management of anaemia associated with chronic renal failure," Drugs, 87, 2675-2682, 1996.

[49] Shikole, A., Spasovski, G., Zafirov, D. and Polenakovic, M.," Epoetin omega for treatment of anemia in maintenance hemodialysis patients," Clin. Nephrol., 57, 237-245, 2002.

[50] Bhopale, G. M. and Nanda, R. K., " Recombinant human erythropoietin: An overview" Indian Drugs, 41, 2707-2713, 2004.

[51] Joy, M. S.," Darbepoetin alfa: A novel erythropoiesis stimulating protein." Ann. Pharmacother., 36, 11831192, 2002.

[52] Swiech K, Picanço-Castro V, Covas DT," Human cells: new platform for recombinant therapeutic protein production, " Protein Expr Purif. Jul;84(1):147-53, 2012.

[53] Jennifer Dumont, Don Euwart, Baisong Mei, Scott Estes \& Rashmi Kshirsagar," Human cell lines for biopharmaceutical manufacturing: history, status, and future perspectives," Critical Reviews in Biotechnology, Early Online: 1-13(2015):

[54] Bhopale, G. M. and Nanda, R. K.,"Blood coagulation factor VIII: An overview," J. Biosci., 23, 783-789, 2003.

[55]Berntorp E, Boulyjenkov V, Brettler D, Chandy M, Jones P, Lee C, Lusher J, Mannucci P, Peak I, Rickard K, et al.,"Modern treatment of haemophilia," Bull World Health Organ. 73(5):691-701, 1995.

[56] Roberts, H. R. and Eberst, M. E.," Current management of haemophilia B," Hematol. Oncol. Clin. North Am., 7, 1269-1280, 1993.

[57] Carr, Jr. M. E. and Martin, E. J.," Recombinant factor VIIa: Clinical applications for an intravenous hemostatic agent with broad spectrum potential," Expert Rev. Cardiovasc. Ther., 2, 661-674, 2004.

[58] Abshire, T. and Kenet, G., "Recombinant factor VIIa: Review of efficacy, dosing regimens and safety in patients with congenital and acquired factor VIII or IX inhibitors," J. Thromb. Haemostatis, 2, 899-909, 2004.

[59] ALPROLIX. (Coagulation factor IX [recombinant] Fc fusion protein) [package insert]. Cambridge, MA: Biogen Idec, Inc. 2014.

[60]ELOCTATE([Antihemophilic factor(recombinant) Fc fusion protein] lyophilized powder for solution for intravenous injection)[package insert]. Cambridge, MA: Biogen Idec Inc. (2014).

[61] Mahlangu J, Powell JS, Ragni MV, et al.," Phase 3 study of recombinant factor VIII Fc fusion protein in severe hemophilia A," Blood, 123, 317-25, 2014.

[62] Powell JS, Pasi KJ, Ragni MV, et al.," Phase 3 study of recombinant factor IX Fc fusion protein in hemophilia B," N Engl J Med, 369, 2313-23, 2013.

[63] Octapharma. European Commission publishes approval of Octapharma's human cell line recombinant FVIII (NUWIQ) across all age groups in haemophilia A. Octapharma press release, 2014 (http://www.octapharma.com)

[64] Butler M, Spearman M.," The choice of mammalian cell host and possibilities for glycosylation engineering," Curr Opin Biotechnol., Dec;30:107-12, 2014.

[65] Barrows, L. R.,Antineoplastic and immunoactive drugs. In The Science and Practice and Pharmacy (ed. Gennaro, A. R.), Remington, p. 1495, 2000.

[66] G. M. Bhopale and R. K. Nanda, " Recombinant DNA expression products for human therapeutic use," Current Science, vol. 89, no. 4, 2005.

[67]Bryson, H. M. and Sorkin, E. M., "Dornase alpha. A review of its pharmacological properties and therapeutic potential in cystic fibrosis," Drugs, 48, 894-906, 1994.

[68] Glaesner W, Vick AM, Millican R, et al., "Engineering and characterization of the long-acting glucagon-like peptide-1 analogue LY2189265, an Fc fusion protein," Diabetes Metab Res Rev, 26,287-96, 2010.

[69] TRULICITY ([Dulaglutide] injection, for subcutaneous use) [package insert]. Indianapolis, IN: Eli Lilly and Company., 2014.

[70]Durocher Y, Butler M.,"Expression systems for therapeutic glycoprotein production," Curr Opin Biotechnol, 20, 700-7, 2009.

[71]Behrens F, Tak PP, Ostergaard M, et al., "MOR103, a human monoclonal antibody to granulocyte-macrophage colony-stimulating factor, in the treatment of patients

\section{Volume 5 Issue 6, June 2016 www.ijsr.net}




\section{International Journal of Science and Research (IJSR) \\ ISSN (Online): 2319-7064}

Index Copernicus Value (2013): 6.14 | Impact Factor (2015): 6.391

with moderate rheumatoid arthritis: results of a phase $\mathrm{Ib} / \mathrm{IIa}$ randomised, double-blind, placebo-controlled, dose-escalation trial," Ann Rheum Dis, 74, 1058-64, 2015.

[72] Nagarajan T, Marissen WE, Rupprecht CE. "Monoclonal antibodies for the prevention of rabies: theory and clinical practice," Antibody Technol J, 4, 112, 2014.

Volume 5 Issue 6, June 2016 www.ijsr.net 